\title{
3D surface scan of the type specimen of Molassitherium delemontense Becker and Antoine, 2013: use of a 3D model for research and conservation issues
}

\author{
Maridet Olivier ${ }^{1,2 *}$, Rauber Gaëtan ${ }^{3}$, Rochat Martine ${ }^{1}$, Roch Renaud ${ }^{1}$, Tissier Jérémy ${ }^{1,2}$, Anquetin Jérémy $^{1,2}$, Becker \\ Damien ${ }^{1,2}$ \\ ${ }^{1}$ Jurassica Museum, Route de Fontenais 21, CH-2900 Porrentruy, Switzerland \\ 2 Département des Géosciences, Université de Fribourg, Chemin du Musée 6, CH-1700 Fribourg, Switzerland \\ ${ }^{3}$ Section d'archéologie et paléontologie, République et Canton du Jura, Office de la Culture, Hôtel des Halles, CH-2900 Porrentruy, Switzerland \\ *Corresponding author: olivier.maridet@jurassica.ch
}

\begin{abstract}
This contribution provides for the first time the 3D model of the type specimen of Molassitherium delemontense (Mammalia, Rhinocerotidae) described in the following publication: Becker et al. (2013), Journal of Systematic Palaeontology, Vol. 11, Issue 8, 947-972, https://doi.org/10.1080/14772019.2012.699007. Conservation issues of the specimen and solutions using 3D model and 3D prints are detailed.
\end{abstract}

Keywords: Conservation, Early Oligocene, Rhinocerotidae, Switzerland

Submitted:2018-12-19, published online:2019-02-19. https://doi.org/10.18563/journal.m3.82

\section{Inv. nr. \\ MJSN POI007-245 Holotype specimen of \\ Molassitherium delemontense}

Table 1. Holotype specimen of Molassitherium delemontense from the JURASSICA Museum (Porrentruy, Switzerland).

\section{INTRODUCTION}

\section{Context of the discovery}

Becker et al. (2013) described a well-preserved skull of Rhinocerotidae from the Early Oligocene locality of Poillat (Canton Jura, NW Switzerland). The skull (MJSN POI007-245, see Table 1) was discovered in 2007 during the prospective excavations related to the construction of the A16 (Transjurane) motorway and is the holotype of the species Molassitherium delemontense Becker and Antoine, 2013 (in Becker et al. 2013); it is stored in the collection of the JURASSICA Museum (formerly 'Musée jurassien des sciences naturelles', MJSN), in Porrentruy (Canton Jura, Switzerland). After screenwashing, the associated small mammals yielded by the same layer were identified and provided an age estimation of $c$. 30-30.5 Ma (late Early Oligocene; Becker et al. 2013). The mammal remains from Poillat were enclosed in Rupelian sandy deposits corresponding to river channel dominated facies of the historic 'Molasse alsacienne' Formation (USM: Lower Freshwater Molasse) of the so-called 'Jura Molasse' (Picot et al. 2008; Becker 2009). A recent lithostratigraphic review proposes a regional standardized framework, from the northern Swiss Jura and the southern Upper Rhine Graben, and lithostratigraphycally assigns the locality of Poillat to the Alsace Group, Niederroedern Formation, Heidwiller Member (Pirkenseer et al. 2018). The type specimen of $M$. delemontense originates from a sandy mud pebble channel.

\section{Excavation and preparation of the specimen}

Since the discovery of the skull in 2007, many conservation issues occurred. The locality was close to a river and the sandy mud sediment was very permeable. As a result the entire site and the fossil remains were soaked in water (resulting in much darker colors compared to the specimen after drying; Fig. 1a,c vs. 1b,d). As soon as the skull was exposed and started to dry, fractures have developed and it started to crumble away. In addition, the sediment surrounding the skull was not homogeneous (Fig. 1a,c). Most of the sediment consisted of soft sandy mud, easy to dig out by brushing (but poorly supporting the bone remains), whereas some parts of the sediment were indurated, closer to a sandstone. The skull was consequently first consolidated on the excavation site using Mowilith 60 dissolved at $5 \%$ in acetone, because it can be used in humid condition. The most friable parts of the bone were preserved by covering them with Japanese paper soaked with Mowilith 60. The skull was then excavated with a large volume of sediment surrounding it in order to avoid a rapid deterioration of the specimen and to complete the extraction in laboratory. In order to prevent any deterioration during the excavation, the skull was encased in a shell of silicone, cast directly on the specimen, itself protected by cellophane packaging to avoid direct contact of the silicone with the bone. Then an additional layer of plaster reinforced with fiberglass was cast on the silicone in order to produce a solid block, easier to excavate.

Before beginning preparation at the laboratory, it was first necessary to slowly dry the specimen and initiate a first phase of consolidation. All along the preparation and conservation processes, reversible methods were favored. Paraloid B72, often used in archeological and paleontological preparations (e.g. Horiec 2010; Berducou 1990; Shelton and Chaney 1994; Keene 1986, 


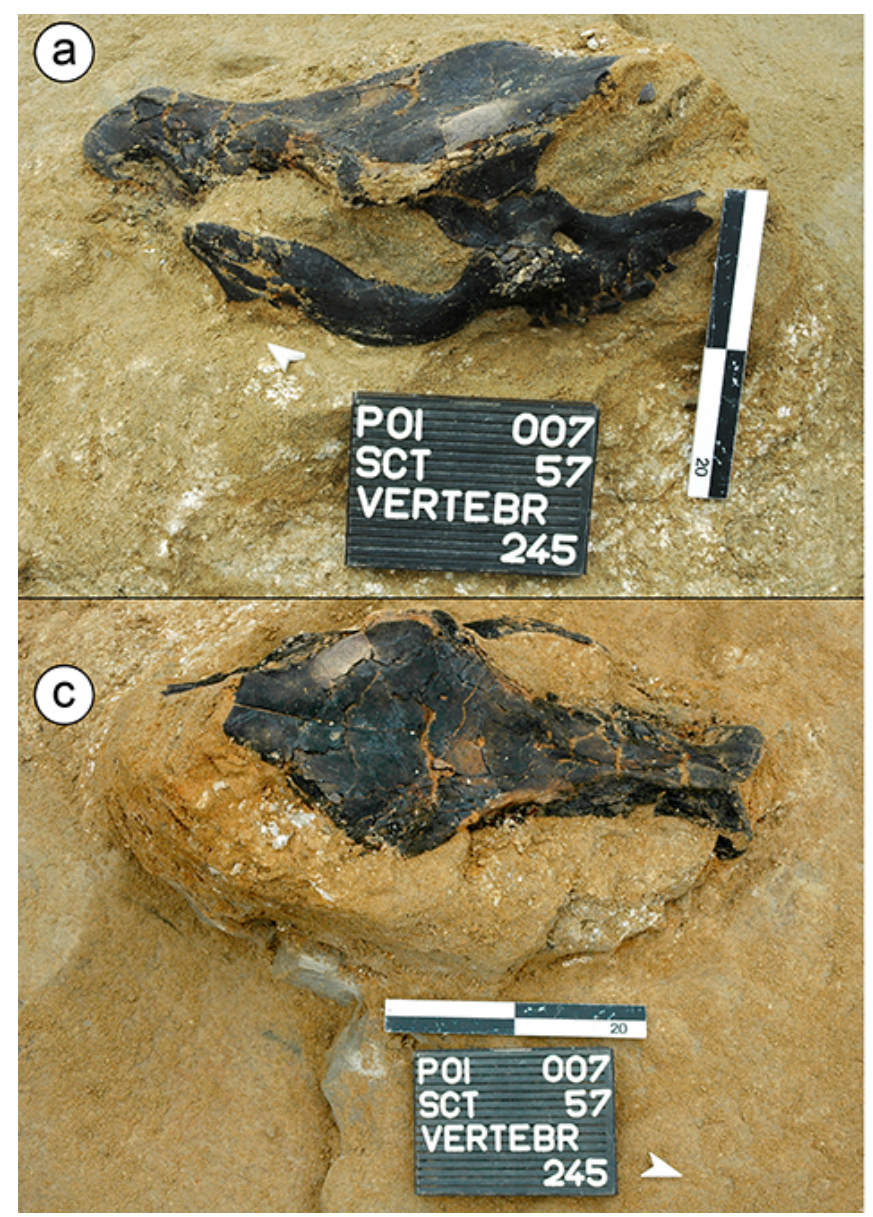

b
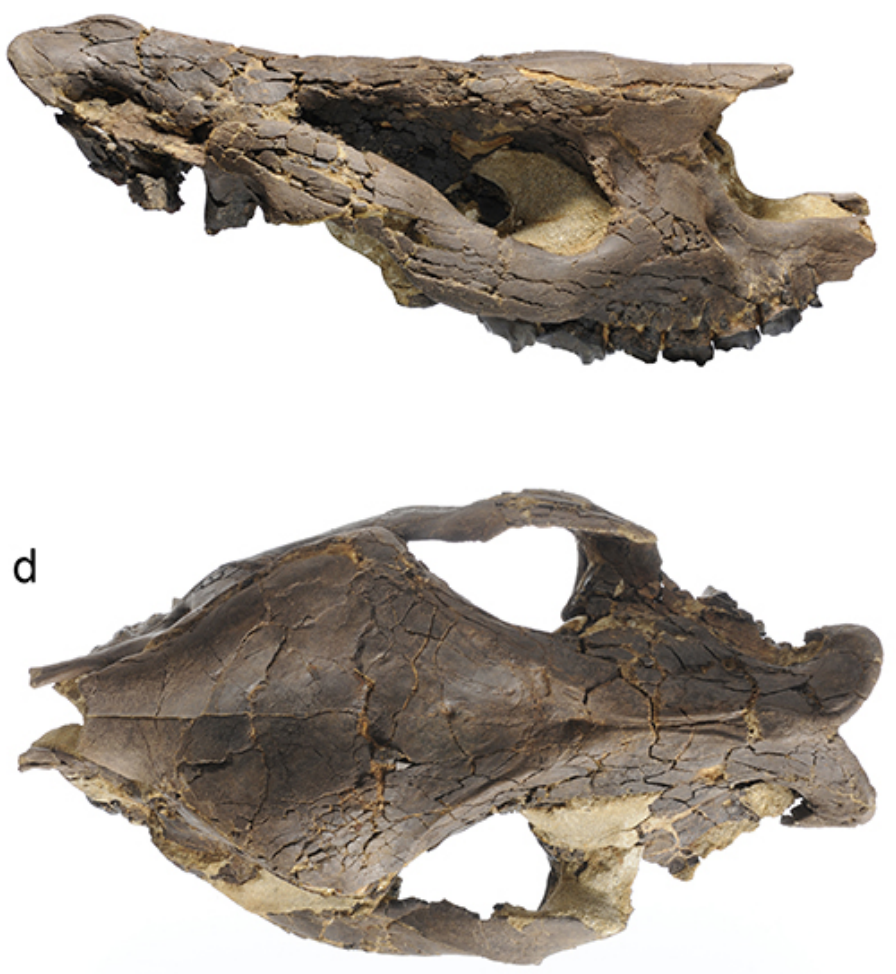

$5 \mathrm{~cm}$

Figure 1. Skull and type specimen of Molassitherium delemontense Becker and Antoine, 2013 (MJSN POI007-245): a) right lateral view of the specimen as found on the excavation site, b) right lateral view of the specimen after extraction and preparation, c) dorsal view of the specimen as found on the excavation site, d) dorsal view of the specimen after extraction and preparation.

1987; Green 2001; López-Polín L. 2012), was chosen due to its well-known features: reversible or reworkable by redissolution and good long term conservation (Bromelle et al. 1984; Podany et al. 2001; Davidson and Brown 2012). In contrast, cyanoacrylate-based consolidants and glues are not reversible, often display coloration alterations with time, not resistant to $\mathrm{UV}$, and become fragile due to stronger retraction effect than with Paraloid (Berducou 1990; Down et al. 1996; Horiec 2010; Tsetsekou et al. 2018). Different solvents can be used with Paraloid B72, for instance aromatic hydrocarbons such as Toluene would have allowed a deeper penetration of Paraloid inside the specimen (Phenix 1992a, b, 1993). But Toluene was not used for security reasons (toxicological effects at contact and inhalation, and negative impact on the environment). In turn for using hydrocarbons, Paraloid was dissolved into acetone at various successive concentrations (3, 5, 7, 10 and 20\%) allowing a progressive penetration in the fossil until saturation. Subsequent preparation of the specimen was mostly carried out using mechanical methods with small manual tools and air-tools. In addition, ethanol was sometimes used to soften the sediment and facilitate its removal. Despite all of the precautions taken during the preparation process, the specimen revealed itself to be much more fragile than expected and several parts broke off, notably the right zygomatic arch and the occipital region. These parts were glued back using either Paraloid B72 dissolved at $40 \%$ in acetone for the larger parts, or cyanoacrylate for the smaller parts (even if not reversible, a fast adhesion is necessary for the smaller parts which are difficult to hold tight). When gluing back large parts, filling voids were sometime necessary to ensure larger bonding surfaces. This was made by mixing glue with either micro marbles of glass (glass being an inert matter), or crushed sediment from the excavation site in order to conceal visible bonding surfaces. Finally, to stabilize the specimen, Paraloid B72 dissolved from 10 to $20 \%$ in acetone was applied all over the skull to consolidate and protect the surface of the fossilized bone (Fig 1b,d).

\section{Conservation issues}

Since 2012, the skull was presented to the public in the exhibition of the JURASSICA Museum (Porrentruy, Switzerland), but progressive deterioration was observed (new crumbling and fractures, detachment of one of the tooth row). The specimen was consequently removed from exhibit and sent back to the laboratory for restoration in September 2014. The skull was first consolidated with Paraloid B72 dissolved at 7\% into acetone and applied by injections into the cracks. Acetone was used locally to help cleaning the surface of the bone when excess of 
a

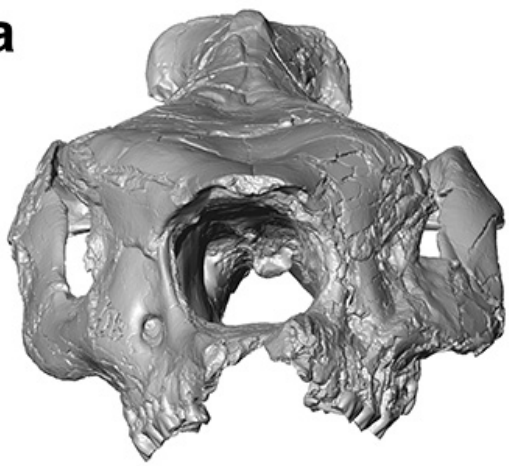

b

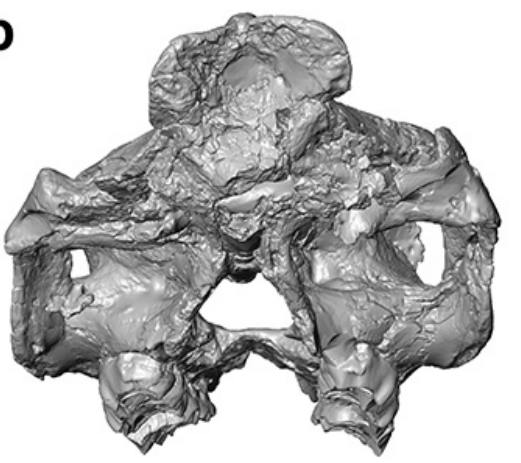

f

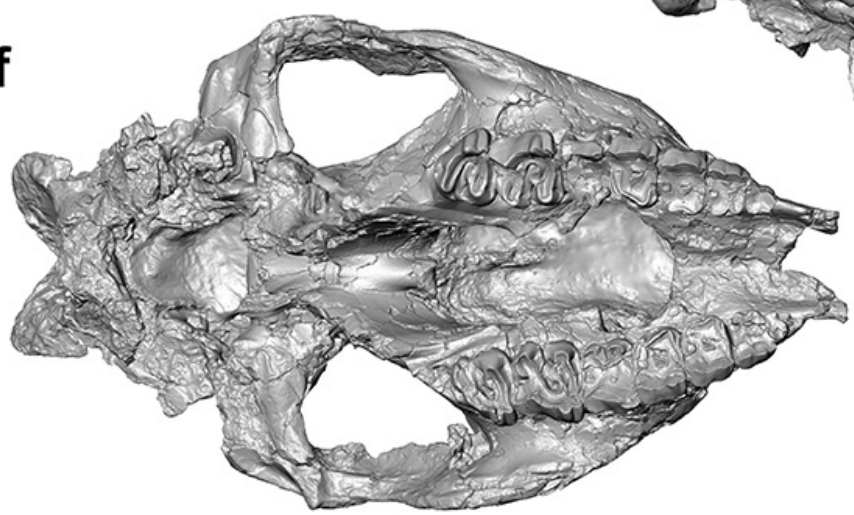

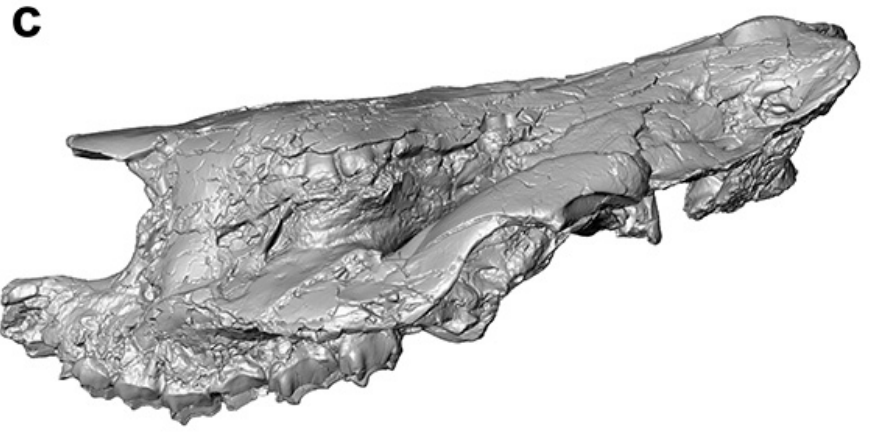

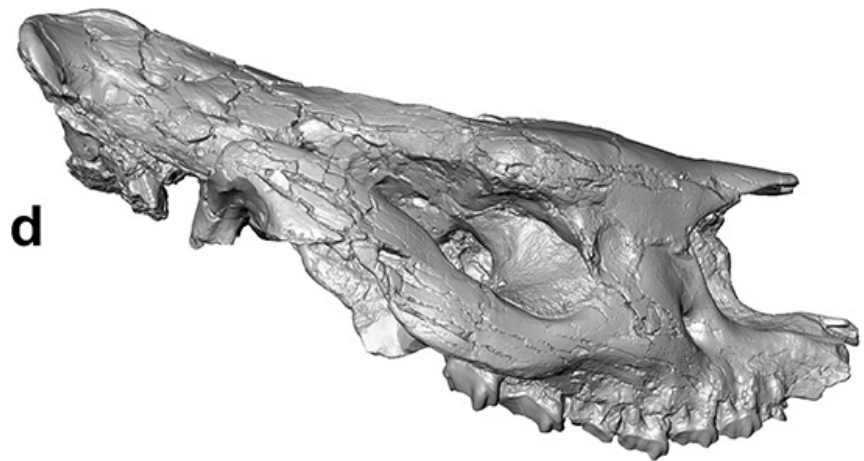

e

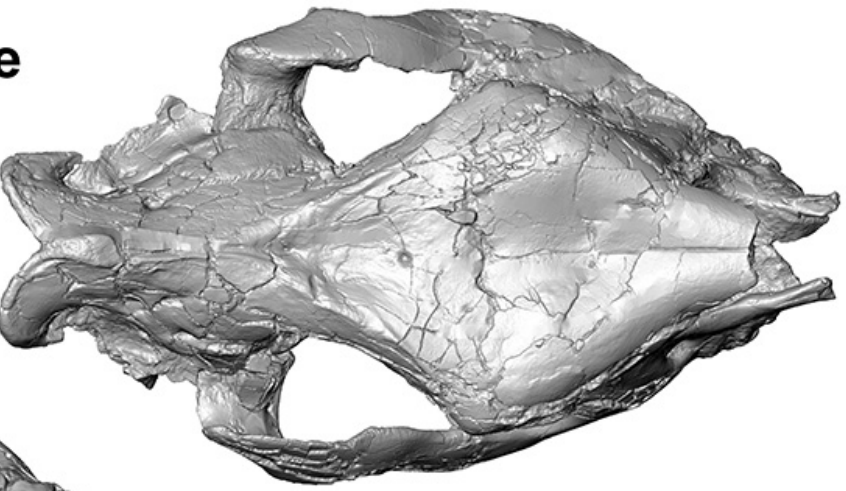

$5 \mathrm{~cm}$

Figure 2. 3D numerical model of the type specimen of Molassitherium delemontense Becker and Antoine, 2013 (MJSN POI007-245): a) anterior view, b) posterior view, c) left lateral view, d) right lateral view, e) dorsal view, f) ventral view. 
Paraloid came out of the cracks. Detailed observations of the damages revealed that the rapid deterioration of the skull was partly due to the presence of very small pyrite crystals inside the specimen (Newman 1998; Weick-Neher 2012). The volume of pyrite crystals increases during oxidation making the surface of the specimen cracks, furthermore, the oxidation reaction of the pyrite also produces small amounts of sulfuric acid contributing to further damage the specimen (Rouchon 2012; Odin et al. 2013). In order to stop the reaction, all of the areas affected by pyrite oxidation were treated with ethanolamine thioglycolate dissolved at 5\% into ethanol and precisely applied by the mean of swabs (Cornish and Doyle 1984; Wolberg 1989; Barlage and Lobbe 2006). Finally a last coat of Paraloid B72 dissolved at $7 \%$ into acetone was applied on all the surface to reduce further reaction of the pyrite with atmospheric humidity (Doyle 2003). Both the consolidation of the fossilized bone and the neutralization of the oxidation reaction succeeded to stabilize the specimen. Nonetheless, despite the various restoration protocols, the specimen remains quite fragile. It was consequently decided to keep it inside a hermetic box in order to protect it as much as possible from humidity and temperature variations. As a result, manipulation of the specimen for either scientific purposes or public outreach must be reduced to the minimum. It was consequently necessary to produce an accurate copy of the specimen. However, the fragility of the skull prevented the use of traditional casting techniques because extraction from the silicone mold would have likely caused extensive damages. The specimen was therefore 3D modeled and printed.

\section{METHODS}

\section{D acquisition}

The surface scanning of the specimen was made using the structured light scanner "Artec Space Spider" (Artec Group, Inc) allowing a precision up to $0.1 \mathrm{~mm}$ of the numerical model and reconstructed with Artec Studio 10 Professional (Fig. 2). The textured 3D surface model is provided in .ply format including color and texture coordinates.

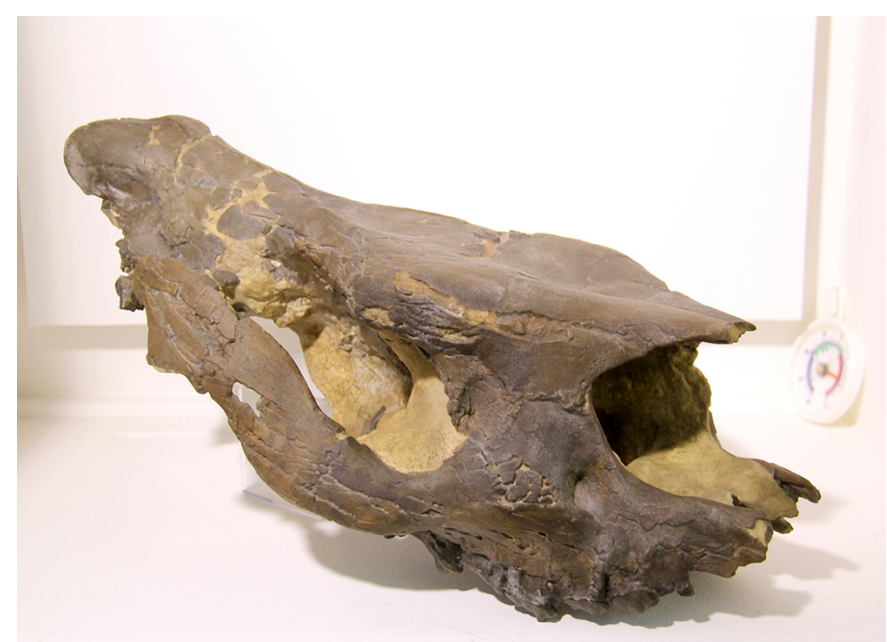

Figure 3. Colored 3D print of the type specimen of Molassitherium delemontense Becker and Antoine, 2013 as presented to the public in the exhibit of the JURASSICA Museum (Porrentruy, Switzerland).

\section{Copy by 3D printing}

Two copies were 3D printed using selective laser sintering (SLS) of polyamid powder allowing an accuracy slightly lower than the numerical model ( $0.15 \mathrm{~mm})$. One of the 3D prints was colored to show an accurate copy of the fossil skull to the public (Fig. 3). Natural pigments were used to produce colors as natural as possible. Natural pigments also present the advantage of being UV-resistant, avoiding their progressive discoloration due to light. Pigments have been mixed with Mowilith dissolved at 5\% in ethanol, and applied with brushes. The coloration of the bony parts was rendered by a mix of Cassel brown earth (dark brown pigment), black iron oxide (black pigment) and natural umber (brown pigment). A mix of black iron oxide and natural Sienna (yellow-brown pigment) has been applied together with shellac (dissolved into alcohol) on the surface of the teeth to produce a shinier enamel-like aspect. The color of the sediment was rendered by a mix of burnt umber (light dark-brown pigment), yellow ochre (tawny pigment), light golden ochre (light rustcolored pigment) and burnt natural Sienna (dark yellow-brown pigment), all applied with a matt polyurethane lack. The whole copy was then varnished with a matt polyurethane coat in order to fix the colorations. Finally, the copy was rubbed with a mix of talcum powder, yellow ochre and golden ochre in order to give a rendering closer to the original texture of the fossil.

\section{CONCLUSION}

Preservation of natural heritage is the main responsibility of curators in all natural sciences collections, including paleontological collections. Conservation of type specimens is especially critical since they are international taxonomic references that must remain accessible to any researcher requesting to study them. This conservation becomes tricky when specimens are fragile and must avoid manipulation in order to prevent further damage. The type specimen of $M$. delemontense, an almost complete skull of rhinocerotid from the early Oligocene, falls within this category where a balance must be found between the necessity to keep it accessible to the scientific community and the need to ensure long-term conservation. This dilemma is usually easily solved by the production of highly accurate casts that can be used by researchers for most of the anatomical comparisons. However, when the specimen is too fragile to make a mold, other solutions must be found. In the case of this skull of $M$. delemontense the choice was made to produce a 3D surface numerical model and to print it. Like casts, 3D prints can be colored, offering to the public a very accurate and realistic copy of the original fossil. For scientific purposes and direct observations, and considering the size of the specimen, 3D prints are detailed enough to show most of the relevant morphological details of the skull and can be used for comparisons. Thanks to these copies, manipulation of the original specimen is limited to brief observations of some specific details, if at all necessary. Finally, through the present publication, the 3D model is now made available to download and study for the whole scientific community. 


\section{ACKNOWLEDGEMENTS}

Grant sponsor: Swiss National Science Foundation. Grant number: 200021-162359. We also thank two referees, Anne-Lise Charruault and Suzanne Jiquel, who have contributed to improve this publication through their comments on previous version of the manuscript.

\section{BIBLIOGRAPHY}

Barlage, M., Lobbe, R. 2006. Konservierung sulfidisierter Fossilien- zwei Methoden im Vergleich. Der Präparator, 52, 84-89.

Becker, D. 2009. Earliest record of rhinocerotoids (Mammalia: Perissodactyla) from Switzerland: Systematics and biostratigraphy. Swiss Journal of Geosciences, 102, 375-390. https: //doi.org/10.1007/s00015-009-1330-4

Becker, D., Antoine, P.-O., Maridet, O. 2013. A new genus of Rhinocerotidae (Mammalia, Perissodactyla) from the Oligocene of Europe. Journal of Systematic Palaeontology, 11, 947-972. https://doi.org/10.1080/14772019.2012.699007

Berducou, M.C. (Coord.). 1990. La conservation en archéologie, Méthodes pratiques de la conservation-restauration des vestiges archéologiques. Elsevier Masson, 469p.

Bromelle, N.S., Pye, E.M., Smith, P., Thomson, G. (Eds). 1984. Adhesives and Consolidants. Preprints Paris Congress, IIC, London.

Cornish, L., Doyle, A. 1984. Use of ethanolamine thioglycollate in the conservation of pyritized fossils. Palaeontology, 27(2), 421-424.

Davidson, A., Brown, G. W. 2012. Paraloid B72 Practical tips for the vertebrate fossil preparatory. Society for the Preservation of Natural History, Collection Forum, 26, 99-119.

Down, J.L., MacDonald, M.A., Tétreault, J., Williams, R.S. 1996. Adhesive testing at the Canadian Conservation Institute - an evaluation of selected polyvinyl acetate) and acrylic adhesives. Studies in Conservation, 41, 19-44.

Doyle, A. 2003. A large scale "microclimate" enclosure for pyritic specimens. The Geological Curator, 7(9), 329-335.

Green, O.R. 2001. A Manual of Practical Laboratory and Field Techniques in Palaeobiology. Dordrecht, Springer Netherlands, 538 p. https://doi.org/10.1007/978-94-017-0581-3

Horiec V. 2010. Materials for Conservation. Organic consolidants, adhesives and coating. Ed. Butterworth Heinemann, London, 489 pp.

Keene, S. 1986. Some adhesives and consolidants used in conservation. The geological curator, 4, 421-425.

Keenes, S. 1987. Some adhesives and consolidants used in conservation. The Geological Curator, 1, 421-425.

López-Polín, L. 2012. Possible interferences of some conservation treatments with subsequent studies on fossil bones: a conservator'overview. Quaternary International, 275, 120-127. https://doi.org/10.1016/j.quaint.2011.07.039
Newman, A. 1998. Pyrite oxidation and museum collections: a review of theory and conservation treatments. The geological curator, 6(10), 363-371.

Odin, G.P., Chabard, D., Rouchon V. 2013. Étude de collections de paléontologie - De la caractérisation à la reproduction des altérations de fossiles dits pyriteux. CeROArt, HS 2013, 1-16.

Phenix, A. 1992a. Solvents for Paraloid B-72. Conservation News, 48, 21-23.

Phenix, A. 1992b. Solvents for Paraloid B-72. Conservation News, 49, 23-25.

Phenix, A. 1993. Solvents for Paraloid B-72. Conservation News, 50, 39-40.

Picot, L., Becker, D., Cavin, L., Pirkenseer, C., Lapaire, F., Rauber, G., Hochuli, P. A., Spezzaferri, S., Berger, J.-P. 2008. Sédimentologie et paléontologie des paléoenvironnements côtiers rupéliens de la Molasse marine rhénane dans le Jura suisse. Swiss Journal of Geosciences, 101, 483-513. https://doi.org/ 10.1007/s00015-008-1275-z

Pirkenseer, C., Rauber, G., Roussé, S. 2018. A revised Palaeogene lithostratigraphic framework for the northern Swiss Jura and the southern Upper Rhine Graben and its relationship to the North Alpine Foreland Basin. Rivista Italiana di Paleontologia e Stratigrafia (Research in Paleontology and Stratigraphy), 124, 163-246. https://doi.org/10.13130/2039-4942/9867

Podany J., Garland K.M., Freeman W.R., Rogers J. 2001. Paraloid B72 as a structural adhesive and as a barrier within structural adhesive bonds evaluations of strength and reversibility. Journal of the American Institute for Conservation, 40, 15-33. https://doi.org/10.2307/3180010

Rouchon, V. 2012. Altération des collections de paléontologie : compréhension des mécanismes, diagnostic, et optimisation des conditions de conservation des fossiles. Coré, 27, 33-35.

Shelton, S.Y., Chaney, D.S. 1994. An evaluation of adhesives and consolidants recommended for fossil vertebrates. In: P. Leiggi, P. May, (eds), Vertebrate palaeontological techniques, vol. I. Cambridge University Press, pp. 35-46.

Tsetsekou E., Platanianaki A., Pournou A. 2018. Assessing wood adhesives used in conservation by testing their bond strength and ageing behavior. Procedia Structural Integrity, 10, 227-234. https://doi.org/10.1016/j.prostr.2018.09.032

Weick-Neher, M. 2012. Nachtrag zur Pyritbehandlungsanlage in Basel. Der Präparator, 58, 68-71.

Wolberg, D.L. 1989. Stabilizing Pyritic Material. The Paleontological Society, Special Publication, 4, 244-248. 